\title{
Russians in Business: An Analytical Study of Culture, Governance and Behavior
}

Evgeny Rudnev ${ }^{1}$

${ }^{1}$ Scientific Department, Academy of Public Administration, Senior Lecture, Ph.D.

\section{ARTICLE INFO}

\section{Keywords:}

Behavior

National culture

Behavior in business

Governance

Mental differences

Russians in business

Psychology in organizations

Organizational culture

\begin{abstract}
The article reveals the specifics of Russian national culture and its role in business. The data of studies of Russians are summarized in behavioral context. The historical periods of Russia's development and governance and their influence on behavior are described in the business environment. The greatest differences are noted between the Russian and AngloSaxon mentality. Russians are described in typical situations at the present stage of Russian economy development - the formal use of IT, bureaucracy, subordination, the importance of personal contacts, and desire to control workers behavior during off-hours.
\end{abstract}

\section{Introduction}

Comparison of American and Japanese governance led to the study of culture and its role in management of organizations.

Pascale (1978) showed that Japanese firms expressed a supportive type of management with collective unions and is not characterized by mobility in business environment between companies. Such differences lead to difficulties in similar practices creating for the work of personnel outside of Japanese culture. In the following, the influence of culture is shown in various aspects - as basis for European states existence (Glatz, 1993), the factor influencing the training (Tomasello, Kruger, Ratner, 1993), trust developing (Doney, Cannon, Mullen, 1998), labor relations (Black, 2005), human resources management (Gerhart, Fang, 2005), unified science of the culture evolution (Mesoud, Whiten, Laland, 2006), the depth of connection between national culture and organizational culture (Gerhart, 2008), deep roots and nation development (Jackson, 2009).

In recent studies, the national culture is associated with the modeling of effective work (Halkos, Tzeremes, 2013), creation of a new product (Eisend, Evanschitzky, Gilliland, 2015), satisfaction (El Din, El Ghetany, 2016), national prosperity (Timmerman, 2016), human development (Gamlath, 2017), gender inequality and the success of women in small and medium businesses (Naidu, Chand, 2017), organizational norms, helping behavior and emotional regulation (Smith, 2017), ethical issues (Chen, Gotti, Kang, Wolfe, 2018).

Over a number of years, the trend in science has been growing, connected with the understanding of national culture and the intersection of cultures in international business (Gabaccia, 2004; Welch, 2010; Khan, Khan, 2015; L'opez-Duarte, Vidal-Su'arez, Gonz'alezD'1az, 2016; Dordević, 2016; Calboli, Wee Loon, 2017). This is due to the globalization of business and internationalization of organizations and social systems. However, business culture in Russia, including in organizations, was studied fragmentarily. Therefore, the

* Corresponding author E-mail address: rudnev_ea@ asou-mo.ru 
purpose of this article is to present the first holistic study of Russian business culture in connection with its cultural and governance development.

\section{Materials and Methods}

A comparison method in the field of human resources management and historical reconstruction was used in research. Interdisciplinary wethords allowed to draw a link between historical development at the macro level and the movement to present - the economy development at country level and behavior in organizations. The topic was deepened from the first studies of national culture factor influence on organization management in the seventies of last century to direction of describing cultural differences in international studies by foreign authors. And then on the national character and differences in organizations by domestic scientists. The analytical and comparison methods. particular, natural experiment and included observation methord, as well as descriptive methods that capture the specifics of mental differences and organizational culture at the national level were used. Complexity methodology allowed to base the foundations for further more detailed studies on behavior in organizations at the national level in business.

\subsection{Development of Russia - historical and cultural aspects of governance}

Historically, the development of Russia is connected with the baptism and the rule of Vladimir Svyatoslavovich Rurikovich (Red Sun) in 988. Before that, the Russian state was a pagan. After the reign of Vladimir, Russia was a confederation of principalities with a kinship population of one language and one faith adjoining the territory to each other. From the 13th to 15 th centuries Russia was under the Mongol-Tatar yoke. Currently, this is disputed by historians. In 1480, after standing on the Ugra, Prince Ivan the Third stopped paying tribute and Moscow principality began to dominate. The first declared himself tzar Ivan the Fourth (Grozny). Initially, the princes were not bound by land (the territory of principalities). The local nobility (vyatshie men) - the local aristocracy, boyars (tycoons) - were formed from ancient Russia. They were considered a tribal nobility. The princes were invited - it was a military nobility. But gradually the princes increased and the accordion became dependent on them and began to serve the princes.

Unlike Russia, Europe did not represent a single union, therefore social processes took place here in competition. Russia was a unitary state (since the 16th century), due to this, the level of inertia of local population is quite high here. Historically, Russia was all under control and a uniform state. In addition, it has borders in Europe and Asia. Social lifts in Russia work poorly, as in France. The geographical position of Russia is such that it is surrounded by Gentiles - Muslims in the East and Catholics in the West. Unlike the West, Russia is quite isolated - as a cultural, linguistic, religious power. In Europe, a person can be quite mobile there is an alternative, autonomy. Religious and social similarities are closer between European countries, not the isolation of population. Peter 1 firmly and uncontestedly introduced Russia into European culture and the European context. Father of Peter Alexei Mikhailovich was the first to write European newspapers. Peter the First laid the tradition the teaching of Russians in European universities. The highest classes were barred beards. Peter founded the European marriages on Russian throne. The custom was to marry the heirs of the Russian Empire with representatives of German dynasties and extradite princesses to the representatives of Western monarchies until the 20th century. Women monarchs were charitable - they supervised the almshouses, educational institutions. Eksterina II - a German by birth, relied on national cadres - Lomonosov and other Russian figures developed national culture. She made it possible for the Germans to come to Russia. Mongolian and subsequent European influence led to the fact that in Russia there was hierarchical and bureaucratic management. To oppose the Mongol yoke princes were forced to unite in a single autocratic 
state, where one king ruled - the Asian method of management (all belonged to one). Under the influence of the Germans, there was a system of education - a classical gymnasium. Civilizational institutions were borrowed from Western Europe. At the same time, the management system remained eastern. Modern Russia is characterized by a centralized type of government with a developed bureaucracy on the ground. There is an interpretation that Russia is still a colonial country, unlike France or Britain. There are Tatarstan and Bashkortostan. However, unlike the countries of Europe, which viewed the colonies as a source of income, in Russia the state invested in small nations. Therefore, the principle of colonial Russia does not fall under the European signs. Traditionally, Russia is considered an agrarian country. The traditional way of life - working in the field in summer determines a temporary perspective here. In summer people make stocks, in winter - they make an exchange. All these determine the psychology in organizations in Russia.

Russia is often compared to the United States. But there are not many similarities - the United States was originally a country of emigrants, and Russia has always been a self-identical country where "outsiders" did not play any significant role.

\subsection{The first studies the behavior of Russians}

Fundamental work on cultural differences to the present time remain G.Hofstede research (2003), singled out the parameters that studied the culture of the world and their impact on organization management. G. Hofstede was one of the first to try in describing the differences in Russian behavior from the culture in business point of view. He noted, that in Russia the wardrobe of a man demonstrates his individual image as a professional, well-cut and dark suits are adopted, the continuation of which are a well-combined with clothing shoes. Men can neglect jackets during negotiations; to keep hands in pockets is not customary. This is seen as ill-bred, ignorant or even insulting.

G.Hofstede quite accurately described the influence of mentality on business relations in Russia. For example, foreigners must be on time at all business meetings, but a Russian colleague may be late, which is a kind of test for waiting for patience, becouse in Russia, do not like ceremonies. "Patience is an extremely important virtue among Russians, punctuality is not. The Russians are known as the greatest assessors (extremely diligent) during the negotiations, by this they demonstrate their patience. The most difficult thing for Russians is to reach a compromise, which is considered a symbol of weakness. In this country, the word "negotiation" is often associated with the word "influence." (Hofstede, 2003) He also singled out some norms of informal communication outside of work. For example, if you are invited to someone's home, it is customary to take with you a bottle of wine, something from a dessert or a bouquet of flowers. There is a norm to shake someone's hand and to remove gloves, otherwise it will be perceived as ill-manner. During the reception of alcohol and food, it is customary to be alive and open. Refusal to behave in this way is considered a serious violation of etiquette.

In Russia, a message and loud laughter in public are perceived as bad taste and ill-manner. However, this behavior is quite common in the youth environment. According, G. Hofstede many Russians speak in English, highly educated. However, at the present stage of economic development, equality of access to quality education is the growing problem. And some services are not available for many Russians.

Studies of the national character conducted by N. Sinyagina in the period from 2002 to 2013 on a sample of 6,500 schoolchildren and students, as well as more than 800 parents and 658 teachers from seven federal districts of Russian Federation, in which Russian schoolchildren named the most important virtue of their fellow tribesmen - courage, but of the negative qualities the most Russian teenagers noted - laziness. (Sinyagina, 2013) 


\subsection{Mental differences of Russians}

Irrationalism is a characteristic of Russia. The Russians are not afraid of paradoxes. A typical example of observation of behavior in the business center restaurant. One of the customers makes an order: "I'm a buckwheat with meat." Another: "I, too, only with rice." The restaurant employee understands what is being said. The girl holds a saucer with one hand, and another with a hot cup of coffee. While the European holds a saucer, on which stands a cup of coffee. Logic does not play such a significant role for Russians, as in the United Kingdom or the United States. While the British or Americans do not justify the reasons in the text, they do not begin to write the text. Russia is a civilization not based on logic. It relies more on intuition. But sometimes this is a stereotype. For example, the British - Christians killed Indians. The greatest contrast exists between the Russian and Anglo-Saxon mentality. In the UK, the problem is to unite people - persons into a group. In Russia - from the mass of people to allocate a person. A long totalitarian type of governance promoted this - the Soviet way of life with a one-party system, a monotonous type of life, the same level of wages and minimal differences between people. In Russia, there are stable expressions that characterize its culture - "a poet in Russia is more than a poet", "not thanks, but in spite of", "one is not a warrior in the field". They point out the difficulties of the formation of the creative personality and its role in the life of nation, as well as the unification of Russians in the situation of difficulties, misfortunes, and militancy of the nation. There are also language differences. In English, the word "I" is always written with a capital letter, in Russian - only at the beginning of the sentence. In all other cases - with a small letter. In general, Russia has a female culture. As a result of the first and second world wars, there were global losses in the country, as a result of which the male potential was greatly lost. The boys received female education. Therefore, in a conflict situation, men often behave like women, and competition is not supported, which leads to the containment of the country's development. For example, attempts to introduce a personalized system of wages in education lead to resistance. Women in Russia live longer than men (77 years against 67). They occupy a dominant role in education, finance, medicine, where it is often difficult for men to make a career. As the dominant values are preserved - relations and social justice. Competition contravenes relations between people, and contradicts the norms of national culture. In this case, equality allows any person to register a company and start work. At the same time, foreign influences and innovations are easily borrowed, everything is absorbed very easily. The country occupies one of the leading position in the spread of IT-technologies. Although the effectiveness of their use is low. In the West, IT is used to simplify work and organization. In Russia, the fact of using IT is very important, but not effectiveness. Often, IT solutions reflect the bureaucratic nature of relationships in the business environment or the function of an intermediary, a very common type of business. In this case, people do not produce anything, but serve as intermediaries between different social groups. In Russia, large spaces and many resources, but at the same time a low standard of living. The most of resources - financial and intellectual - are concentrated in large cities - Moscow (a capital and the largest European city), St. Petersburg, Novosibirsk, Yekaterinburg, Nizhny Novgorod, Samara, Omsk, Kazan, Chelyabinsk, Rostov on Don and other cities. Traditionally, the strongest administrative resource - executive, legislative and judicial authorities - is concentrated in Moscow. Historically, St. Petersburg was the capital of Russian Empire from 1712 to 1728 and from 1732 to 1918. Until some time between Moscow and St. Petersburg there was a confrontation in science and influence in cultural life. At present, it has been overcome, although substantial differences remain. Both cities are distinguished by high conglomeration of newcomers, there are differences in vocabulary, linguistic pronunciation and way of life. Muscovites are more philistine, rude, hasty, business, cynical, life-loving, not knowing the measures. Petersburgers - intelligent, measured, chamber, aspiring to a better life. A 
significant time period between the capitalist type of government in the state (1917-1991) created a historical situation, when the capitalist type of relations is practically recreated in the country. At the same time, the state plays an essential role in all spheres of life now and in business too. Most of the initiatives are owned and controlled by the state - national projects "Education", "Medicine", "Leaders of Russia". While private initiatives are rarely supported by the state or even alien to it. Therefore, modern Russian entrepreneurs are often loyal to the state, unlike the United States, where the private capital has always ruled. In this regard, Russia is in a permanent state of development since the early nineties of the last century. To date, the country has not developed a business culture. This is of interest for the study of people's behavior in organizations.

\subsection{Description of behavior in Russian business}

Bystritskaya (2001) in the study of small businesses found that in small businesses "the orientation toward survival is 1.7 times more likely to dominate than" development orientation, "" new management methods are needed 1.6 times less frequently than the methods of solving managerial tasks, and 1,5 times less often "plan such decisions". $88 \%$ of the participants in the study had units or persons responsible for organizing the process of implementing "higher values, 65\% - special programs linking these values with measures to improve labor productivity, 50\% - targeted training courses for personnel to adopt such values.

The basis for slogans reflecting the ideology of professionalism in each case is socially meaningful understanding ("the process is the most reliable product of ours", "the best things for a better life through chemistry") Dominate hiring by the principle - it is easier to teach than to retrain.

Traditionally, managers at Russian enterprises play a dominant role, and the processes of recognition of merit are very difficult. Andreeva (2005) showed that in Russian organizations, "the discrepancy between the professional environment and the employee's expectations is widespread, the management does not recognize the professional skills of specialists, ignores the employee's ideas and initiatives, lacks a sense of belonging to the company, a sense of professional achievement, personal and professional growth, as well as the absence of changes in the status of employee." This is due to recognition at later career stages, which makes the Russian business culture related to the Asian, where there is respect for the elders and with Italian culture, where the power is an magical significance. With the development of information technology and the change of generations, we can find more information about leadership on the websites of Russian organizations. However, there are two extremes - there is information - there are no contacts (mail), there are contacts of the management - there is no information about top management. This indicates a limited access to leadership - an increased level of power distance. In Russian organizations, subordination matters. It is not customary to solve the problem without discussing it with the immediate supervisor. There is a stable expression that characterizes the relationship "leader subordinate" - do not jump over the head. Lygdenova (2010), examining the value foundations of organizational culture in Russia, noted that Russian organizations have control from the center, as in France, "there is an alienation between workers and bosses." And if Holland is characterized by "horizontal collectivism", Russia has a high power distance. For Russian organizations are typical - celebrations of landmark days, joint ventures on nature, sports events, company birthday. On the one hand, this indicates the dominance of the family structure in management in many Russian organizations. And on the other, about the desire to control the personal life of employees and in their spare time. This indicates a violation of the rights to rest in Russia. Refusal to participate in such events can lead to negative reaction from management and other employees, entails isolationism, a violation of the working 
climate and labor relations. In other words, in Russian organizations, free time is often seen as working. In Russia there is a stable norm associated with the introduction of changes in organizations. If you are asked to do something - do not hurry to do the work. If you were asked to do this a second time, you need to think about it. If you were asked to do it the third time, you should do the work. (Ushakov, 2004)

Business contacts are established in Russia specifically. The device for work, sometimes obtaining the necessary information occurs by acquaintance, as in France. Business correspondence is conducted formally. In contrast to the US, where e-mail and information technology serve as a means of business communication. In Russia, it is not accepted to reply to emails. This is considered a waste of time. Therefore, if the letter is sent, then there is a call on the mobile phone to the contact person. Either there is a norm when people first negotiate or agree on the essence of the matter, and then send information by e-mail, after which a business negotiations result can be achieved. At business conferences often, however, it is not always possible to observe the speeches of referents, experts without discussing the content of the report. Unlike the United States, where a smile is a symbol of success, and in Japan - has a double meaning, both positive and negative, in Russia, a smile means a positive attitude as in European countries. However, in Russia it is not customary to smile, that's why Russians are often perceived as an unfriendly nation. On the other hand, both thinking - globally, and locally at the same time.

Most Russians aspire to receive higher education. However, the fact of obtaining an education does not guarantee a higher level of wages or status in the organization. The degree of MBA is often obtained to confirm the status or increase personal income, and not to promote the market or professional growth. One of Russia's problems is low income, low productivity, lack of education tie with career growth.

\section{Discussion}

The development of the modern business culture of Russians was influenced by the historical development of country - the eastern hierarchical and European bureaucratic, as well as the agrarian type the way of life - work in summer and exchange in winter. For Russia, there is a female type of culture - relationships and social justice, which hinders the development of competition and business, and the foreign success and positive results violate social justice. The issue of the collectivist nature of business relations remains questionable in connection with the geographical position of Russia. However, the historical development and the character of stable expressions indicate a strong collectivist spirit of the nation. In support of this and the centralized nature of governance with the concentration of basic resources in major cities, which more corresponds to the Asian type, in contrast to the culture of the United States, where the leading universities are located throughout the country and not only in the capital. Russians attach importance to education. However, education in Russia is not a guarantee of success, which can also be related to the female type of culture. Observation of behavior in the business environment and its analysis show, that in Russia the status of image is emphasized, the image of professional. And at the same time, the difficulty of identifying a person in a group, the formal use of IT, bureaucracy, subordination, the importance of personal contacts, the desire to control behavior in off-hours. In this paper, an attempt is made to conduct the first holistic study of the behavior of Russians in business in order to continue conducting research in this field in future and use the results obtained for more productive work in international business.

\section{References}

Andreeva TA (2005) Why do the best go: the problem of personnel demotivation. Company management. No. 2. pp. 24-27 
Black B. (2005) Comparative industrial relations theory: the role of national culture. International Journal of Human Resource Management. 16:7, 1137-1158

Bystritskaya Y.V. (2001) Organizational culture of small enterprises: sociological aspect: dis. cand. sociol. sciences (Ph.D.) Moscow State Social University, Moscow. 185p.

Chen C., Gotti G., Kang T., Wolfe M.C. (2018) Corporate Codes of Ethics, National Culture, and Earnings Discretion: International Evidence. Journal of Business Ethics. 151:141-163

El Din H. F., El Ghetany H. (2016) The Relationship between Organizational Culture and Job

Satisfaction: An International Perspective. Proceedings of the 4th European Conference on Management, Leadership \& Governance. pp.101-109

Dordević B. (2016) Impact of national culture on international human resources management. Ekonomske teme. 54(2): 281-300

Doney P.M., Cannon J.P., Mullen M.R. (1998) Understanding the influence of the national culture on development of trust. Academy of Management Review. Vol.23, No.3, 601-620

Eisend M. , Evanschitzky H., Gilliland D.I. (2015) The Influence of Organizational and National Culture on New Product Performance. Journal of Product Innovation Management 33(3):260-276

Halkos G. E., Tzeremes N.G. (2013) Modelling the effect of national culture on countries' innovation performances: A conditional full frontier approach. International Review of Applied Economics. Vol. 27, No. 5, 656-678

http://geert-hofstede.international-business-center.com/mcsweeney.shtml

Gabaccia D. (2004) Cultures in Contact. IRSH 49, pp. 475-515

Gamlath S. (2017) Human Development and National Culture: A Multivariate Exploration. Social Indicators Research. 133:907-930

Geographical indications at the crossroads of trade, development, and culture. Focus on AsiaPassific. (2017) Ed. by Calboli I., Wee Loon N.-L. Cambridge University Press. 530p.

Gerhart B., Fang M. (2005) National culture and human resource management: assumptions and evidence. International Journal of Human Resource Management. J6:6, 971-986

Gerhart B. (2008) How Much Does National Culture Constrain Organizational Culture? Management and Organization Review. 5:2 241-259

Glatz F. (1993) State, state nation, cultural nation. European Rewiew. Vol. 1, No. 4, 385-389

Jackson L. Renaissance, Regeneration, and Reform: The Culture of Protestantism and the Remaking of America. Rebirth of a Nation: The Making of Modern America, 1877-1920. New York: HarperCollins, 2009, 406 p.

Khan S.R., Khan I.A. (2015) Understanding Ethnicity and National Culture: A Theoretical Perspective on Knowledge Management in the Organization. Knowledge and Process Management. Vol. 22, No.1 pp.51-61

L'opez-Duarte C., Vidal-Su'arez M.M., Gonz'alez-D'ıaz B. (2016) International Business and National Culture: A Literature Review and Research Agenda. International Journal of Management Reviews, Vol. 18, 397-416 
Lygdenova V.V. (2010) Axiological foundations of Russian organizational culture. dis. cand. philosopher. sciences. RAS, Siberian Branch, Institute of Philosophy and Law. Novosibirsk. 146 p.

Mesoudi A., Whiten A., Laland K.N. (2006) Towards a unified science of cultural evolution. Behavioral and brain sciences. 29, 329-383

Naidu S., Chand A. (2017) National Culture, Gender Inequality and Women's Success in Micro, Small and Medium Enterprises. Social Indicators Research. 130:647-664

Pascale R.T. (1978) Personnel Practices and Employee Attitudes: A Study of Japanese and American Managed Firms in the United States. Human Relations. Vol. 31, No.7, pp. 597617

Peretz H., Fried Y., Levi A. (2018) Flexible work arrangements, national culture, organizational characteristics, and organizational outcomes: A study across 21 country. Human Recourses Management Journal. 28: 182-200

Sinyagina N.Y. (2013). Ethnic relations in student environment. National education. No.1, pp. 234-236.

Smith P.B. (2017) Cultural Values Versus Cultural Norms as Predictors of Differences in Helping Behaviors and in Emotion Regulation: A Preliminary Nation-Level Test Related to the Leung-Morris Model. Management and Organization Review. 13:4, 739-766

Timmerman T.A. (2016) Does national culture predict national prosperity? Proceedings of the Academy of Organizational Culture, Communications and Conflict Vol.21, №1, pp.4649

Tomasello M., Kruger A.C., Ratner H.H. (1993) Cultural learning. Behavioral and brain sciences. 16, 495-552

Ushakov K.M. (2004) Development of organization: in search of adequate theories. September, Moscow. 160 p.

Venaik S., Brewer P. (2016) National culture dimensions: The perpetuation of cultural ignorance. Management Learning. Vol. 47(5) 563-589

Welch D. (2010) A Cultural Theory meets cultures of theory. International Theory. 2:3, 446453 